\title{
Effects of Hydro and Osmo-Priming on seed Vigor of pea (Pisum sativum L)
}

\author{
Alihan COKKIZGIN \\ Vocational School of Higher Education in Nurdagi, Organic Farming Department, Gaziantep University, Nurdagi, Gaziantep, Turkey
}

Email address:

acokkizgin@gantep.edu.tr

\section{To cite this article:}

Alihan COKKIZGIN. Effects of Hydro and Osmo-Priming on Seed Vigor of Pea (Pisum sativum L). Agriculture, Forestry and Fisheries. Vol. 2, No. 6, 2013, pp. 225-228. doi: 10.11648/j.aff.20130206.14

\begin{abstract}
Study was conducted to determine the effects of osmo-priming on germination of pea seeds (Pisum sativum L). Experiment was arranged under completely randomized design (CRD) with three replicates. This study was conducted in germination cabinet at Gaziantep University Vocational School of Higher Education in Nurdagi during February-May 2013. Seeds were primed in various osmotic potential of polyethylene glycol-6000 (-0.3, -0.6, -0.9 and -1.2 MPa) and distilled water $(2.5 \mu \mathrm{s} / \mathrm{cm})$ at $20{ }^{\circ} \mathrm{C}$ for 24 hours and there was also a control treatment. In this study, 3 pea cultivars (Utrillo, Carina and Rondo) were used and germination tests were carried out in dark conditions in a germination cabinet held at $20{ }^{\circ} \mathrm{C}$ and $50 \%$ relative humidity for 8 days. The beneficial and harmful effects of priming depend on the organism physiology and aim of this study Hydro and Osmo-Priming effects on germination in pea (Pisum sativum L.) seeds. Seedling length, germination percentage, vigor index values varied between treatments $1.32-5.85 \mathrm{~cm}, 48.33-86.39 \%$ and $73.54-543.89$, respectively. Results showed that Carina cultivar is more resistant to osmotic stress than other pea cultivars (Rondo and Utrillo).
\end{abstract}

Keywords: Pea (Pisum Sativum L.), PEG-6000, Osmo-Priming, Hydro-Priming, Germination

\section{Introduction}

Legumes are the third largest family of flowering plants, with more than 650 genera and 18.000 species [1]. Legumes have a major contribution to diet as good sources of protein, carbohydrates, several water-soluble vitamins, and minerals [2]. The garden pea (Pisum sativum?) may have originated in Ethiopia, or the Mediterranean and Central Asia with a centre of diversity in the Near East [3].

Peas are a nutritious legume, containing 15 to $35 \%$ protein, and high concentrations of essential amino acids such as lysine and tryptophan [4]. In the world, dry pea has 6.2 million ha harvest area of, and a total of production of 9.6 million $t$, while green pea has 2.2 million ha harvest area and 17 million $\mathrm{t}[5]$.

Seed germination is usually the most critical stage in seedling establishment, determining successful crop production [6]. On the other hand seed priming has been successfully shown to improve germination and emergence in seeds of many crops [7]. However, pea is particularly sensitive to osmotic stress [8]. Some investigators recorded an accumulation of proline (Pyrrolidine-2-carboxylic, a non-essential amino acid) in all plants exposed to osmotic stress [9]. Besides, germination was reduced with increased osmotic stress of the seeds [10]. It is reported that growth of tropical pasture legume plants were reduced under the osmotic stress [11]. The aim of this study were to determine the effects of osmo-priming (The soaking of seed in Peg-6000 prior to sowing) and hydropriming (The soaking of seed in water prior to sowing) on germination of pea (Pisum sativum L) seeds.

\section{Material and Methods}

Utrillo, Carina and Rondo pea cultivars were used and in this study, seeds were surface-sterilized with $5 \%$ sodium hypochlorite $(\mathrm{NaOCl})$ [12] and washed thoroughly with distilled water $(2.5 \mu \mathrm{s} / \mathrm{cm})$. The seeds were germinated in 120 $\mathrm{mm}$ petri dishes that were sterilized at $170^{\circ} \mathrm{C}$ for 4 hours in the hot air sterilizer [13]. Seeds are not held after washing and just started implementation of priming.

Seeds were primed in various osmotic potential of polyethylene glycol-6000 $(-0.3,-0.6,-0.9$ and $-1.2 \mathrm{MPa})$ and distilled water $(2.5 \mu \mathrm{s} / \mathrm{cm})$ at $25{ }^{0} \mathrm{C}$ for 24 hours. Ten $\mathrm{ml}$ of appropriate solution was added to each Petri dish. Distilled water osmotic potential was $0.0 \mathrm{MPa}$ and on the other hand, there was a control treatment (untreated seeds). All seeds cleaned with distilled water at the end of the 24 hours for 
cleaning of the PEG-6000.

A total of 20 seeds were put in each Petri dish on double-layer Whatman paper and placed in germination cabinet at a temperature of $20^{\circ} \mathrm{C}$ and $50 \%$ RH for 8 days [14]. The petri dishes were arranged in a completely randomized design (CRD) with three replications. During the germination period, the Petri dishes were observed daily. Each day, $5 \mathrm{ml}$ of distilled water $(2.5 \mu \mathrm{s} / \mathrm{cm})$ was added to each Petri dish. A pea seed was considered to has germinated when the radicle reached a length of $10 \mathrm{~mm}$ [15].

\subsection{Seedling Length}

Seedling length was the total length of radicle and plumule and it was measured in centimeters with using caliper [16].

\subsection{Germination Percentage \%}

Germinated seeds were counted daily according to the seedling evaluation procedure in the Handbook of Association of Official Seed Analysts. The number of germinated seeds was recorded every $24 \mathrm{~h}$ [17]. After 8 days of seed, the germination percentage was calculated using the formula below for each replicate of the treatment [16].

GP $(\%)=$ Number of germinated seed / Number of total seed $\times 100$

\subsection{Seed Vigor Index}

The Seed Vigor Index was calculated, using formula [18], as:

Seed Vigor Index $=$ [Seedling length $(\mathrm{cm}) \times$ GP $(\%)]$

\subsection{Statistical Analysis}

The results were evaluated by analysis of variance using the Statistical Analysis System software v.9.0 [19]. The experimental design comprised completely randomized blocks (CRD) with three replicates and means of treatment were considered significantly different at $p=0.05$. Mean separation was performed by Least Significant Difference (LSD) test [20].

\section{Results and Discussion}

\subsection{Seedling Length}

No significant differences were observed among PEG-6000 treatments with respect to seedling length. However seedling length for seeds primed with pure water was higher than that for osmo-primed and unprimed seeds. Hydropriming treatment has highest value $(4.01 \mathrm{~cm})$ of seedling length and -1.2 MPa osmotic potential has lowest value $(2.42 \mathrm{~cm})$ (Table 1 and Figure 1). Generally seedling length was gradually decreasing with increasing osmotic potential. It is reported that the highest germination rate was obtained for seeds primed with water, but this trait did not differ significantly compared to between other seed treatments [21]. On-farm seed priming is a simple, low cost intervention, and its impact is large enough to induce farmers to make other, changes in agronomic practices, perhaps more risky or more costly, in order to make further gains [22].

According to statistical analysis results Carina pea cultivar significantly differed from other genotypes in terms of seedling length (Table 2).

Table 1. Hydro and osmo priming effects for all measurement parameters in pea*

\begin{tabular}{|c|c|c|c|}
\hline $\begin{array}{c}\text { Osmotic Potential } \\
\text { (MPa) }\end{array}$ & $\begin{array}{c}\text { Seedling } \\
\text { length }(\mathrm{cm})\end{array}$ & $\begin{array}{c}\text { Germinatio } \\
\text { n }(\%)\end{array}$ & $\begin{array}{c}\text { Seed Vigor } \\
\text { Index }\end{array}$ \\
\hline $\begin{array}{c}\text { Control (No } \\
\text { priming) }\end{array}$ & 3.71 & $70.00 \mathrm{a}$ & 317.6 \\
\hline 0.0 (Hydropriming) & 4.01 & $70.00 \mathrm{a}$ & 351.3 \\
\hline-0.3 & 2.45 & $62.78 \mathrm{ab}$ & 172.8 \\
\hline-0.6 & 2.64 & $57.78 \mathrm{ab}$ & 195.9 \\
\hline-0.9 & 2.71 & $62.78 \mathrm{ab}$ & 212.7 \\
\hline-1.2 & 2.42 & $51.11 \mathrm{~b}$ & 179.4 \\
\hline
\end{tabular}

*Means followed by the same letter(s) are not significantly different at $\mathrm{P}=$ 0.05

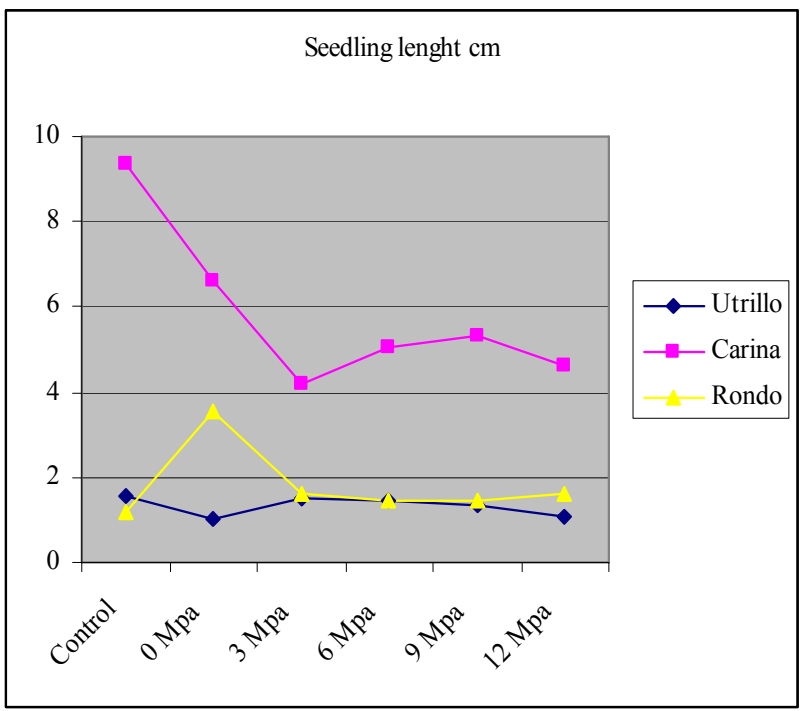

Figure 1. Change in seedling length, depending on the polyethylene glycol-6000 concentration

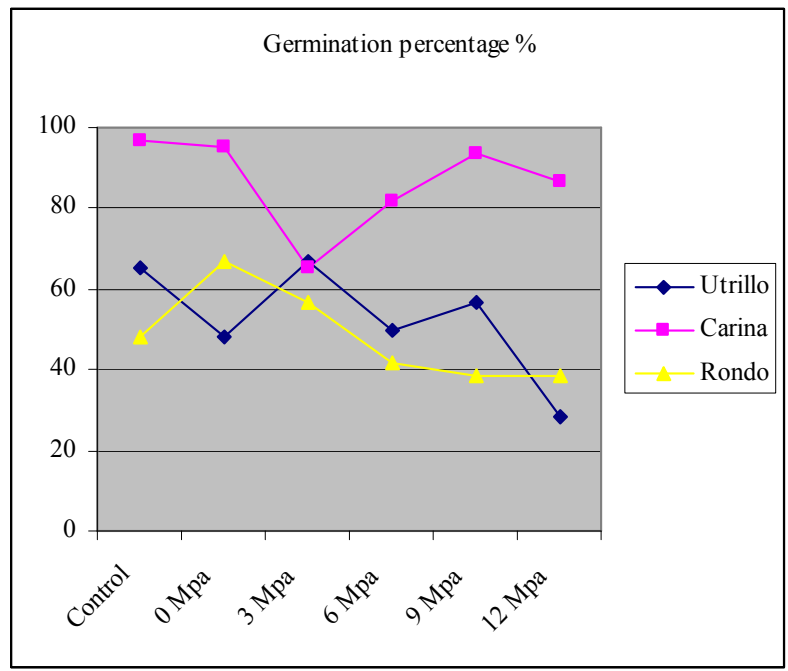

Figure 2. Change in germination percentage, depending on the polyethylene glycol-6000 concentration 


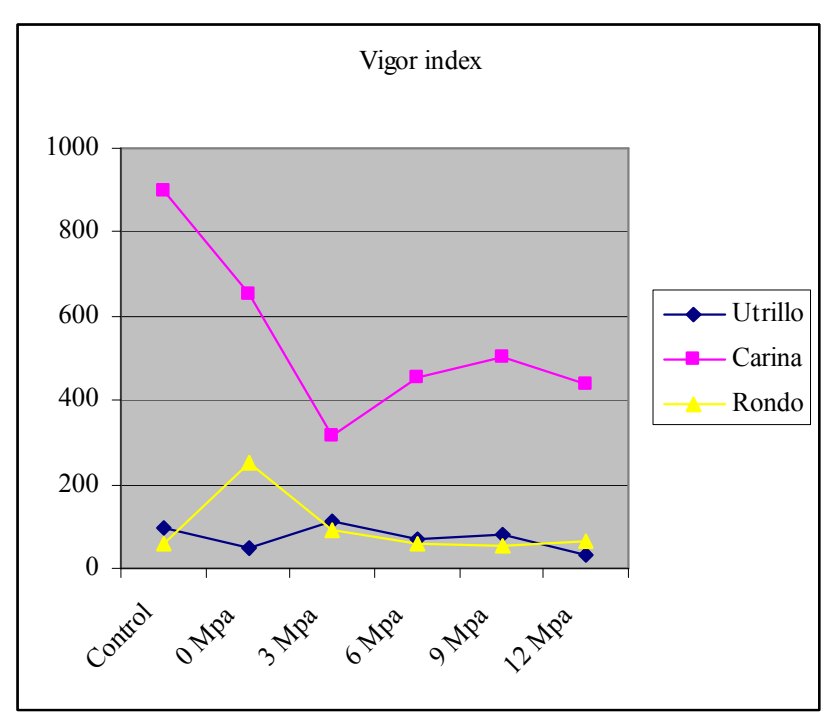

Figure 3. Change in seed vigor index values, depending on the polyethylene glycol-6000 concentration

\subsection{Germination Percentage}

Significant differences were found among treatments in terms of germination percentage $(\mathrm{p}=0.05)$. Germination percentage was negatively affected by PEG-6000 treatments. Hydropriming and non-priming treatments has highest germination percentage value $(70 \%)$. In terms of cultivars, $\mathrm{cv}$. Carina has $86.39 \%$ germination and this value is the highest among the varieties (Figure 2). Chemical compound has the positive or negative effects on germination. The germination percentage was decreased with increasing osmotic potentials [23].

Table 2. Cultivar means for all measurement parameters in pea

\begin{tabular}{llll}
\hline Cultivars & $\begin{array}{l}\text { Seedling } \\
\text { length }(\mathbf{c m})\end{array}$ & Germination (\%) & Seed Vigor Index \\
\hline Utrillo & $1.32 \mathrm{~b}$ & $52.50 \mathrm{~b}$ & $73.5 \mathrm{~b}$ \\
Carina & $5.85 \mathrm{a}$ & $86.39 \mathrm{a}$ & $543.9 \mathrm{a}$ \\
Rondo & $1.81 \mathrm{~b}$ & $48.33 \mathrm{~b}$ & $97.4 \mathrm{~b}$ \\
\hline
\end{tabular}

*Means followed by the same letter(s) are not significantly different at $\mathrm{P}=$ 0.05

\subsection{Seed Vigor Index}

Seed vigor index was not significantly affected by osmotic potential treatments. However increase in Peg-6000 concentration, decreased seed vigor index (Figure 3). Various osmotic potentials $(0,-0.05,-0.1$ and $-0.5 \mathrm{MPa})$ indicated that PEG adversely affected the seed vigor index [24]. Decreasing seed vigor index is probably due to decreasing trend in seedling length. On the other hand according to statistical analysis, significant differences were observed between cultivars and the highest seed vigor index value was obtained from Carina cv. (543.9) whereas the lowest was for cv. Utrillo (73.5).

\section{Conclusion}

According to the results, all studied parameters were negatively affected when the osmotic potential was increased. Hydropriming has a positive effect on all measured parameters. Furthermore, cv. Carina has the highest values for seedling length, germination percentage and seed vigor index parameters. Carina cultivar is more resistant to osmotic stress than other pea cultivars.

\section{References}

[1] G. Lewis, B. Schrirer. B. Mackinder, and M. Lock, "Legumes of the World"; Royal Botanical Gardens: Kew, United Kingdom; 2005.

[2] C. Rodriguez, J. Frias, C. Vidal-Valverde, A. Hernandez, "Correlations between some nitrogen fractions, lysine, histidine, tyrosine and ornithine contents during the germination of peas, beans, and lentils". Food Chemstry, 2008; 108: 245-252.

[3] N. I. Vavilov, "Phytogeographic basis of plant breeding. The origin, variation, immunity and breeding of cultivated plants". Chronica Botanica. 1951; 13: 1-366

[4] T. Elzebroek, and K. Wind, Guide to cultivated plants. CAB International, $540 \mathrm{pp}, 2008$

[5] FAO. Food and Agriculture Organization of the United Nations. 2011 Accessed 15 May 2013 Available: http://www.fao.org

[6] M. Almansouri, J.M. Kinet, and S. Lutts, "Effect of salt and osmotic stresses on germination in durum wheat (Triticum durum Desf.)". Plant and Soil, 2001; 231: 243-254.

[7] E, Donaldson, W. F. Schillinger, and M. D. Stephen. 2001. Straw production and grain yield relationships in winter wheat. Crop Sci. 41: 100-106.

[8] D.R. Wilson, P.D. Jamieson, W.A. Jermyn, R. Hanson, Models of growth and water use of field peas (Pisum sativum L.). pp. 139-151 in: The pea crop: a basis for improvement. Hebblethwaite, P. D.; Heath, M. C.; Dawkins, T. C. K. ed. London, Butterworths; 1985.

[9] R.P.S. Chauhan, C.P.S. Chauhan, and D Kumar. "Free proline accumulation in cereals in relation to salt tolerance". Plant and Soil. 1980; 57: 167-175.

[10] W.R. Akeson, M.A. Henson, A.H. Freytag, and D.G. Westfall, "Sugar beet fruit germination and emergence under moisture and temperature stress". Crop Science, 1980; 20: 735-739

[11] E.M. Hutton, "Variation in salt response between tropical pasture legumes". Sabrao Newsletter, 1971; 3: 75-81.

[12] D.B. Sauer, and R. Burroughs. "Disinfection of seed surfaces with sodium hypochlorite". Phytopathology, 1986; 76: 745-749.

[13] Z. Muhammad and F. Hussain. "Effect of $\mathrm{NaCl}$ salinity on the germination and seedling growth of some medicinal plants". Pak. J. Bot., 2010; 42(2): 889-897.

[14] ISTA. Rules Proposals for the International Rules for Seed Testing 2011 Edition. International Seed Testing Association. 53p. Secretariat, Zürichstrasse 50, CH-8303 Bassersdorf, Switzerland, 2011. 
[15] S.H. Goertz, and J.M. Coons, "Germination response of tepary and navy beans to sodium chloride and temperature". Hortscience, 1989; 24 (6): 923-925.

[16] AOSA. Seed Vigor Hand Testing Book. p. 122-128. Contribution No. 32 to the Handbook on Seed Testing. Association of Official Seed Analysis. Springfield, USA; 1983.

[17] A. Tanveer, A. Rehman, M.M. Javaid, R.N. Abbas, M. Sibtain, A. Ahmad, M.S. Zamir, K.M. Chaudhary, and A. Aziz. "Allelopathic potential of Euphorbia helioscopia L. against wheat (Triticum aestivum L.), chickpea (Cicer arietinum L.) and lentil (Lens culinaris Medic.)". Turk J Agric For 2010; $34: 75-81$.

[18] A.A. Baki, and J.D. Anderson, "Vigour determination in soybean by multiple criteria". Crop Sci., 1973; 13: 630-633.

[19] SAS. SAS/STAT 9.1. User's guide: Statistics. SAS institute Inc., Carry, NC, USA, 5121pp; 2004.

[20] O. Duzgunes, T. Kesici, and F. Gurbuz. Statistical Methods I. Ankara University, Agricultural Engineering Faculty Press, Ankara, Turkey, 229 pp; 1983.
[21] K. Ghassemi-Golezani, A.A. Aliloo, M. Valizadeh, and M. Moghaddam. "Effects of Hydro and Osmo-Priming on Seed Germination and Field Emergence of Lentil (Lens culinaris Medik.)". Not. Bot. Hort. Agrobot. Cluj 2008; 36(1): 29-33.

[22] D. Harris, A. Joshi, P.A. Khan, P. Gothkar, and P.S. Sodhi, "On-farm seed priming in semi-arid agriculture development and evaluation in maize, rice and chickpea in India using participatory methods". Experimental Agriculture, 1999; 35, $15-29$.

[23] M. Abbasi, H. Pouzesh, A. Enayati, and A. Hedayati. "Investigation the effect of hydropriming and osmopriming treatments on seeds germination of Tall Wheatgrass (Agropyron elongatum) under drought stress". Annals of Biological Research, 2012; 3(10): 4874-4879

[24] M. Gholami, M. Rahemi, and B. Kholdebarin. "Effect of drought stress induced by polyethylene Glycol on Seed Germination of four wild almond species". Australian Journal of Basic and Applied Sciences, 2010; 4(5): 785-791.: University Science, 198. 